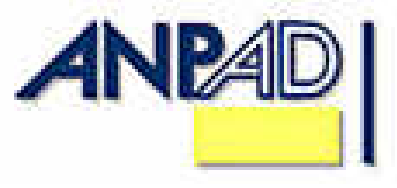

Available online at

http://www.anpad.org.br/bar

BAR, Curitiba, v. 5, n. 4, art. 1, p. 260-274,

Oct./Dec. 2008

\title{
The Relationship between Logistics Sophistication and Drivers of the Outsourcing of Logistics Activities
}

\author{
Peter Wanke * \\ E-mail address: peter@coppead.ufrj.br \\ COPPEAD - Universidade Federal do Rio de Janeiro \\ Rio de Janeiro, RJ, Brazil. \\ Rebecca Arkader \\ E-mail address: rebecca@coppead.ufrj.br \\ COPPEAD - Universidade Federal do Rio de Janeiro \\ Rio de Janeiro, RJ, Brazil.

\section{Maria Fernanda Hijjar} \\ E-mail address: nanda@coppead.ufrj.br \\ COPPEAD - Universidade Federal do Rio de Janeiro \\ Rio de Janeiro, RJ, Brazil.
}

\begin{abstract}
A strong link has been established between operational excellence and the degree of sophistication of logistics organization, a function of factors such as performance monitoring, investment in Information Technology [IT] and the formalization of logistics organization, as proposed in the Bowersox, Daugherty, Dröge, Germain and Rogers (1992) Leading Edge model. At the same time, shippers have been increasingly outsourcing their logistics activities to third party providers. This paper, based on a survey with large Brazilian shippers, addresses a gap in the literature by investigating the relationship between dimensions of logistics organization sophistication and drivers of logistics outsourcing. To this end, the dimensions behind the logistics sophistication construct were first investigated. Results from factor analysis led to the identification of six dimensions of logistics sophistication. By means of multivariate logistical regression analyses it was possible to relate some of these dimensions, such as the formalization of the logistics organization, to certain drivers of the outsourcing of logistics activities of Brazilian shippers, such as cost savings. These results indicate the possibility of segmenting shippers according to characteristics of their logistics organization, which may be particularly useful to logistics service providers.
\end{abstract}

Key words: logistics sophistication; logistics outsourcing; drivers of logistics outsourcing.

Received 02 October 2007; received in revised form 11 August 2008.

Copyright (C) 2008 Brazilian Administration Review. All rights reserved, including rights for translation. Parts of this work may be quoted without prior knowledge on the condition that the source is identified.

* Corresponding author: Peter Wanke

COPPEAD Graduate School of Business, Federal University of Rio de Janeiro, Rua Paschoal Lemme 355,

Cidade Universitária, Ilha do Fundão, Rio de Janeiro, RJ, 91941-918, Brazil. 


\section{INTRODUCTION}

The achievement of logistics excellence, i.e., the ability of a company to obtain at the same time low costs and improved service levels has been the object of extensive research over the last years (Bowersox, Closs, \& Stank, 1999).

In addition, there has been a trend since the 1980s to outsource non core logistics activities (Sink \& Langley, 1997). In fact, companies have been turning increasingly to third party logistics providers (3PL) to carry out their logistics activities, both in the US (Knemeyer \& Murphy, 2004; Lieb \& Randall, 1996; Rabinovich, Windle, Dresner, \& Corsi, 1999) and in Europe (Laarhoven, Berglund, \& Peters, 2000). The logistics services market has been growing steadily worldwide. Annual expenditure by US shippers represented 40 percent of their logistics budget in 2003, compared with between 19 and 30 percent in the four previous years, and 80 percent were using outsourced logistics to help manage overseas supply chains (Morris, 2004). The same study reported an expected industry revenue growth of 14 percent over the coming years (Morris, 2004). A more recent study reports impressive figures for the percentage of outsourced activities in the logistics budget of shippers in North America (48 percent), Asia-Pacific (63 percent), Western Europe (64 percent) and Latin America (39 percent) (Capgemini, 2006). In fact, with a certain delay regarding other contexts such as the US or Europe, Brazilian shippers have been intensifying their use of outsourced logistics functions since the midnineties (Figueiredo, Fleury, \& Wanke, 2003). This increased demand is being met by an extraordinary growth in the third-party logistics service provider (also known as contract logistics) industry: its annual turnover is estimated to have grown from US\$ 1 billion to about US\$ 9 billion between 1997 and 2005 (Tecnologística, 2006).

Literature reveals several reasons for the outsourcing of logistics activities, mostly linked to achieving cost reduction on the one hand, and flexibility on the other (Boyson, Corsi, Dresner, \& Rabinovitch, 1999; Londe \& Maltz, 1992). However, different shippers may opt to outsource their logistics activities due to different motives, according to their logistics organizational profile (Daugherty \& Droge, 1997; Selviarides \& Spring, 2007). Therefore, the degree of sophistication of a company's logistics function may be related to the motives it has to outsource logistics activities. For instance, it may be expected that shippers with less sophisticated logistics organizations are motivated by cost reduction factors, whereas companies with more sophisticated logistics organizations are driven to outsource in order to improve flexibility or to expand their market coverage. The objective of this paper is to bridge a gap in the literature in terms of clarifying this link by investigating the relationship between the dimensions behind the sophistication of the logistics function of manufacturing shippers and their motivation to outsource logistics activities. It therefore aims to contribute to the literature on logistics outsourcing by linking different sophistication factors to the reasons why shippers seek to outsource their logistics activities. This is done mainly by answering the following research questions: (1) what are the main components of the dimensions that characterize the sophistication of the logistics organization? and (2) is there a relationship between dimensions of logistics sophistication and the drivers of logistics outsourcing? In addition, the paper has considerable relevance for practice, as its results should help providers to segment their customers according to the sophistication and characteristics of their logistics functions by means of a better understanding of what drives different categories of shippers to outsource their logistics activities.

The following section reviews the conceptual background for the research, focusing on the dimensions considered in previous studies to determine logistics sophistication and the motives driving shippers to outsource logistics activities. Research questions and methodology are detailed in the third section, followed by the presentation and discussion of the results. The concluding section indicates the main contributions of the paper and suggests future issues to promote further understanding of the phenomena. 


\section{CONCEPTUAL BACKGROUND}

\section{The Sophistication of the Logistics Function}

The concept of logistics sophistication stems from the Leading Edge Best Practice Model proposed in the seminal work of Bowersox, Daugherty, Dröge, Germain and Rogers (1992). This model has inspired a rich stream of research (among others, Chee-Chuong \& Chew-Been, 1999; Closs, Godsby, \& Clinton, 1997; Daugherty, Stank, \& Rogers, 1992; Lavalle \& Fleury, 2000; Stank, Rogers, \& Daugherty, 1994; Rogers, Daugherty, \& Stank, 1992). In this model, internal logistics initiatives, here called logistics sophistication, were made up of three dimensions: the degree of organizational formalization, the use of information technology, and the use of indicators to monitor performance. The degree of organizational formalization of the logistics function relates to the status of the chief logistics executive in the firm's organizational structure. Traditionally, the responsibility for logistics activities in the firm was fragmented and dispersed (Amstel \& Starreveld, 1993) and the hierarchical level of functional managers was low (Bowersox \& Closs, 1996), implying a low degree of coordination. A higher level of sophistication in the logistics function would in part reflect a relevant position of the chief logistics manager in the top ranks of the firm, which would facilitate the integrated management of logistics activities and more efficient choices in the function's typical tradeoffs (Daugherty et al., 1992; Lambert \& Stock, 1998).

Also according to this model, the use of information technology to collect, analyze and transfer large quantities of information impacts the swiftness of decision making in the logistics function and, as a consequence, leads to shorter operational cycles and less traumatic adaptations (Bowersox \& Daugherty, 1995).

Finally, cost and service performance monitoring is concerned with the systematic control of logistics activities looking at continuous improvement. The systematic use of performance indicators linked to costs and to customer service has been shown to lead to a better understanding of the function as a whole and to positively impact system flexibility (Lavalle \& Fleury, 2000; Stank et al., 1994).

\section{Drivers of the Outsourcing of Logistics Activities}

There has been extensive research over the past years on the possible drivers of the outsourcing of logistics activities. In order to identify the main drivers of logistics outsourcing, a thorough literature search was conducted of previous studies in the main journal databases (such as Proquest, Science Direct, Emerald and Ebsco). Results are shown below in Table 1.

Table 1: Literature on Main Drivers of Logistics Activities Outsourcing

\begin{tabular}{|l|l|l|l|}
\hline Article & Method & Locus & Drivers Identified \\
\hline Buck (1988) & theoretical & UK & flexibility; concentrate on core business \\
\hline Cavinato (1989) & theoretical & US & cost reduction \\
\hline $\begin{array}{l}\text { Fernie } \\
(1989)\end{array}$ & $\begin{array}{l}\text { interview survey w/ } \\
\text { distribution directors } \\
\text { from major multiple } \\
\text { retail groups }\end{array}$ & US & $\begin{array}{l}\text { service; use of assets; need for specialized } \\
\text { expertise }\end{array}$ \\
\hline Sheffi (1990) & Theoretical & - & $\begin{array}{l}\text { focus on core business; better transportation } \\
\text { solution (service); cost savings; technical } \\
\text { expertise and IT; better equipped logistics } \\
\text { services }\end{array}$ \\
\hline $\begin{array}{l}\text { Bardi \& Tracey } \\
(1991)\end{array}$ & $\begin{array}{l}\text { survey with members of } \\
\text { the CLM- multi industry }\end{array}$ & US & $\begin{array}{l}\text { cost reduction; need for specialized } \\
\text { expertise; asset reduction; expanding } \\
\text { workload }\end{array}$ \\
\hline
\end{tabular}


(conclusion)

Table 1: Literature on Main Drivers of Logistics Activities Outsourcing

\begin{tabular}{|c|c|c|c|}
\hline Article & Method & Locus & Drivers Identified \\
\hline $\begin{array}{l}\text { Londe } \\
\text { and Maltz } \\
(1992)\end{array}$ & $\begin{array}{l}\text { survey with members of } \\
\text { the CLM and WERC - } \\
\text { multi industry }\end{array}$ & US & $\begin{array}{l}\text { space requirements; change in logistics } \\
\text { management; labor costs; new markets and } \\
\text { products; instituting a quality program; } \\
\text { M\&A }\end{array}$ \\
\hline $\begin{array}{l}\text { Szymankiewicz } \\
\text { (1994) }\end{array}$ & $\begin{array}{l}\text { survey with large } \\
\text { shippers }\end{array}$ & UK & $\begin{array}{l}\text { increase flexibility; improve service; reduce } \\
\text { cost; avoid investment }\end{array}$ \\
\hline $\begin{array}{l}\text { Rao and Young } \\
\text { (1994) }\end{array}$ & $\begin{array}{l}\text { case studies by means of } \\
\text { personal interviews with } \\
15 \text { Fortune } 500 \text { shippers }\end{array}$ & $\begin{array}{l}\text { US and } \\
\text { Europe }\end{array}$ & $\begin{array}{l}\text { focus on core activities; service; cost } \\
\text { savings; downsizing; risk and control; } \\
\text { systems and IT; market intelligence }\end{array}$ \\
\hline $\begin{array}{l}\text { Sink, Langley and } \\
\text { Gibson (1996) }\end{array}$ & $\begin{array}{l}\text { focus group with multi } \\
\text { industry shipper } \\
\text { representatives }\end{array}$ & US & $\begin{array}{l}\text { corporate costs/headcount reduction; } \\
\text { product/market line expansion, especially } \\
\text { internationally; increasing customer } \\
\text { demands; need to preserve capital or reduce } \\
\text { risk }\end{array}$ \\
\hline $\begin{array}{l}\text { Lieb and Randall } \\
\text { (1996) }\end{array}$ & $\begin{array}{l}\text { survey with Fortune } 500 \\
\text { shippers }\end{array}$ & US & $\begin{array}{l}\text { cost reduction; access to data; improve } \\
\text { operations; improve customer services; focus } \\
\text { on core competence; flexibility }\end{array}$ \\
\hline $\begin{array}{l}\text { Sink and Langley } \\
\text { (1997) }\end{array}$ & $\begin{array}{l}\text { survey, multi industry, } \\
\text { large shippers }\end{array}$ & $\begin{array}{l}\text { US and } \\
\text { Europe }\end{array}$ & $\begin{array}{l}\text { cost reduction; increase flexibility; improve } \\
\text { service; reduce headcount; focus on core } \\
\text { competence; reduce capital expenditures; } \\
\text { availability of expertise; IT }\end{array}$ \\
\hline $\begin{array}{l}\text { Razzaque and } \\
\text { Sheng (1998) }\end{array}$ & theoretical & - & $\begin{array}{l}\text { expansion to foreign markets; use of JIT } \\
\text { practices and operations complexity; new } \\
\text { systems and technology; flexibility; } \\
\text { retrenchment to core business; M\&A }\end{array}$ \\
\hline $\begin{array}{l}\text { Bhatnagar, Sohal } \\
\text { and Millen (1999) }\end{array}$ & $\begin{array}{l}\text { Survey, multi-industry, } \\
\text { list of registered } \\
\text { companies in Singapore }\end{array}$ & Singapore & $\begin{array}{l}\text { cost savings; flexibility; focus on core } \\
\text { business; customer satisfaction (service); } \\
\text { employee morale; productivity } \\
\text { improvement; access to up-to-date } \\
\text { technology }\end{array}$ \\
\hline $\begin{array}{l}\text { Boyson et al. } \\
\text { (1999) }\end{array}$ & $\begin{array}{l}\text { Survey with } \\
\text { Transportation and } \\
\underline{\text { Distribution subscribers }}\end{array}$ & US & $\begin{array}{l}\text { cost savings or revenue enhancing potential; } \\
\text { focus on core business; solving a problem } \\
\text { area; redesign or reengineering of supply } \\
\text { chain }\end{array}$ \\
\hline $\begin{array}{l}\text { Laarhoven et al. } \\
(2000)\end{array}$ & $\begin{array}{l}\text { interview based survey } \\
\text { with large shippers }\end{array}$ & Europe & $\begin{array}{l}\text { cost reduction; service improvement; } \\
\text { strategic flexibility; focus on core activities; } \\
\text { change implementation }\end{array}$ \\
\hline $\begin{array}{l}\text { Wilding and } \\
\text { Juriado (2004) }\end{array}$ & $\begin{array}{l}\text { survey with consumer } \\
\text { goods companies }\end{array}$ & Europe & $\begin{array}{l}\text { tap into higher competences; flexibility; cost } \\
\text { savings; focus on core business; avoiding } \\
\text { investment; expansion to new markets }\end{array}$ \\
\hline $\begin{array}{l}\text { Sahay and Mohan } \\
\text { (2006) }\end{array}$ & $\begin{array}{l}\text { survey with } 2002 \text { top } 500 \\
\text { organizations in India }\end{array}$ & India & $\begin{array}{l}\text { cost reduction; core competence; service } \\
\text { competence; improved return of assets; } \\
\text { improved inventory turns; improved } \\
\text { productivity }\end{array}$ \\
\hline $\begin{array}{l}\text { Sohail, Bhatnagar } \\
\text { and Sohal (2006) }\end{array}$ & survey, multi industry & Malaysia & time saving; cost saving; improved service \\
\hline
\end{tabular}

As shown in Table 1, there seems to be a consensus that the key drivers of the outsourcing of logistics activities by shippers are cost reduction and service improvement, as well as a focus on core activities and flexibility, leading to the identification the first four relevant drivers of logistics activities considered in this study - cost reduction; improved logistics service provided to the customer; focus on core competences; and improved flexibility in logistics operations. Previous literature, as indicated, also led to the identification of six other relevant drivers included in the study - 
investment reduction; increased control of logistics activities; higher efficiency in execution; knowhow for new logistics solutions; enhanced use of information technology; and market expansion.

\section{METHODOLOGY}

In order to achieve the objectives of this paper, and taking into consideration the constructs and variables revealed by the literature as reviewed in the preceding section, two research questions were addressed: (1) the identification of the main components of the dimensions that characterize the sophistication of logistics organization construct, based on variables measuring logistics organizational formalization, the use of information technology, and performance measurement (Bowersox et al., 1992); and (2) the relationship of logistics sophistication dimensions with drivers of logistics outsourcing.

An empirical study based on data collected in 2005/2006 in a survey with large manufacturing shippers in Brazil was undertaken to answer the proposed questions. The survey population consisted of the 340 manufacturing companies included in the Exame 500 Melhores e Maiores list, a Brazilian annual magazine listing similar to Fortune 500. All companies were contacted by telephone in order to verify whether they outsourced logistics activities and were willing to participate in the research (and in this case to obtain the name of the person involved with decision making to whom the survey instrument would be sent). Questionnaire items were developed based on previous literature and were initially tested by means of in-depth interviews with three large Brazilian companies and focused on the most important logistics outsourcing process that these companies had experienced. The resulting document was then screened by five academics and practitioners in order to identify possible problems and inconsistencies. As a result, minor modifications were introduced. A pre-test was conducted with five shippers in order to ensure that the final research instrument would be well understood by target respondents and in order to validate both structure and content. Based on observations from these pilot respondents a few questions were removed from the original questionnaire.

The electronic questionnaire was then sent out by e-mail to a mailing list of 218 shippers that had agreed during the preliminary telephone contacts to participate in the research. The final sample considered in this study consists of the 93 shippers that returned the questionnaires (a response rate of 42.6 percent of questionnaires sent, representing 27.4 percent of the population of manufacturing companies in the Exame listing). The inexistence of non-response bias was verified by cross-tabulation of the frequency distributions of the responses in terms of industry in the sample against corresponding data from the population. Information on the sample is summarized in Table 2.

Table 2: Characterization of Companies in the Sample

\begin{tabular}{|c|l|l|c|c|l|}
\hline $\begin{array}{c}\text { Type of } \\
\text { Industry }\end{array}$ & Industry & $\begin{array}{l}\text { Sample } \\
\text { Respondents) }\end{array}$ & Population & $\begin{array}{l}\text { Sample } \\
\text { Demographics }\end{array}$ & $\begin{array}{l}\text { Population } \\
\text { Demographics }\end{array}$ \\
\hline \multirow{3}{*}{ Durable Goods } & Automotive & 15 & 37 & $16.1 \%$ & $10.9 \%$ \\
\cline { 2 - 6 } & Electrical Appliances & 7 & 31 & $7.5 \%$ & $9.1 \%$ \\
\cline { 2 - 6 } & Technology & 4 & 25 & $4.3 \%$ & $7.4 \%$ \\
\hline
\end{tabular}


(conclusion)

Table 2: Characterization of Companies in the Sample

\begin{tabular}{|c|c|c|c|c|c|}
\hline $\begin{array}{c}\text { Type of } \\
\text { Industry }^{\text {a }}\end{array}$ & Industry & $\begin{array}{l}\text { Sample } \\
\text { (Respondents) }\end{array}$ & Population & $\begin{array}{l}\text { Sample } \\
\text { Demographics }\end{array}$ & $\begin{array}{l}\text { Population } \\
\text { Demographics }\end{array}$ \\
\hline \multirow{5}{*}{$\begin{array}{c}\text { Non-durable } \\
\text { Goods }\end{array}$} & Food & 11 & 48 & $11.8 \%$ & $14.1 \%$ \\
\hline & Beverage & 6 & 13 & $6.5 \%$ & $3.8 \%$ \\
\hline & Tobacco & 1 & 3 & $1.1 \%$ & $0.9 \%$ \\
\hline & Health-care & 4 & 14 & $4.3 \%$ & $4.1 \%$ \\
\hline & Printing and Publishing & 3 & 26 & $3.2 \%$ & $7.6 \%$ \\
\hline \multirow{5}{*}{$\begin{array}{l}\text { Intermediate } \\
\text { Goods }\end{array}$} & Chemical & 16 & 55 & $17.2 \%$ & $16.2 \%$ \\
\hline & Pulp and Paper & 6 & 17 & $6.5 \%$ & $5.0 \%$ \\
\hline & Plastics and Rubber & 1 & 8 & $1.1 \%$ & $2.4 \%$ \\
\hline & Steel & 11 & 39 & $11.8 \%$ & $11.5 \%$ \\
\hline & Construction Equipment & 5 & 12 & $5.4 \%$ & $3.5 \%$ \\
\hline & Total & 93 & 340 & $100.0 \%$ & $100.0 \%$ \\
\hline \multicolumn{2}{|c|}{ Total Durable Goods } & 29 & 105 & $31.2 \%$ & $30.9 \%$ \\
\hline \multicolumn{2}{|c|}{ Total Non-durable goods } & 25 & 104 & $26.9 \%$ & $30.6 \%$ \\
\hline \multicolumn{2}{|c|}{ Total Intermediate Goods } & 39 & 131 & $41.9 \%$ & $38.5 \%$ \\
\hline \multicolumn{2}{|r|}{ Grand Total } & 93 & 340 & $100.0 \%$ & $100.0 \%$ \\
\hline
\end{tabular}

(a) No significant differences between sample and population distributions were determined using Kendall's Tau-B, Kendall's Tau-C and Gamma.

Nineteen previously identified variables (Bowersox et al., 1992) possibly related to logistics sophistication of shippers were investigated in order to order to answer the first question. The variables, their operationalization and scales are shown in Table 3.

Table 3: Characterization of Variables Related to Logistics Sophistication

\begin{tabular}{|l|l|l|l|}
\hline Construct Component & Variable & Scale & $\begin{array}{l}\text { Type of } \\
\text { Scale }\end{array}$ \\
\hline $\begin{array}{l}\text { Organizational } \\
\text { Formalization }\end{array}$ & $\begin{array}{l}\text { 1- hierarchical level of chief } \\
\text { logistics executive }\end{array}$ & $\begin{array}{l}5 \text { to 1 scale according to } \\
\text { usual Brazilian management } \\
\text { position denominations, } \\
\text { where 5 corresponds to the } \\
\text { topmost management level }\end{array}$ & Ordinal \\
\hline
\end{tabular}




\section{(conclusion)}

Table 3: Characterization of Variables Related to Logistics Sophistication

\begin{tabular}{|c|c|c|c|}
\hline Construct Component & Variable & Scale & $\begin{array}{l}\text { Type of } \\
\text { Scale }\end{array}$ \\
\hline $\begin{array}{l}\text { Use of IT (software and } \\
\text { decision support systems) }\end{array}$ & $\begin{array}{l}\text { 2- vehicle tracking } \\
\text { 3- routing } \\
\text { 4- delivery scheduling } \\
\text { 5- radio frequency } \\
\text { 6- bar coding } \\
\text { 7- separation } \\
\text { 8- address systems } \\
\text { 9- freight auditing } \\
\text { 10- sales forecast } \\
\text { 11- purchase scheduling } \\
\text { 12- supplier management } \\
\text { 13- loading status monitoring } \\
\text { 14- EDI } \\
\text { 15- ERP systems } \\
\text { 16- inventory management in } \\
\text { customer facilities }\end{array}$ & $\begin{array}{l}1=\text { yes } \\
0=\text { no }\end{array}$ & nominal \\
\hline \multirow[t]{2}{*}{ Performance Monitoring } & $\begin{array}{l}\text { 17- frequency of monitoring } \\
\text { related to costs } \\
18 \text { - frequency of monitoring } \\
\text { related to service level }\end{array}$ & $\begin{array}{l}\text { 5= daily/weekly; } 4= \\
\text { monthly/bimonthly; } 3=\text { each } \\
\text { semester; } 2=\text { yearly; } 1=\text { no } \\
\text { monitoring }\end{array}$ & ordinal \\
\hline & $\begin{array}{l}\text { 19- Quantity of monitored } \\
\text { indicators }\end{array}$ & Numeric $(\geq 0)$ & ratio \\
\hline
\end{tabular}

In order to extract dimensions of logistics sophistication the observations for the 19 variables collected in the 93 questionnaires were submitted to factor analysis with Varimax standardized rotation. Results for dimensions are shown in the following section.

The comprehensive review of previous studies (cf. Table 1 above) on the outsourcing of logistics activities led to the identification of ten variables identified as main drivers of the outsourcing of logistics activities. The drivers of logistics outsourcing used for addressing the second research question are characterized in Table 4. 
Table 4: Characterization of Variables Related to Drivers of Logistics Outsourcing

\begin{tabular}{|c|c|c|c|}
\hline Construct Component & Variable & Scale & $\begin{array}{l}\text { Type of } \\
\text { Scale }\end{array}$ \\
\hline $\begin{array}{l}\text { Shipper drivers of logistics } \\
\text { outsourcing }\end{array}$ & $\begin{array}{l}\text { 1- } \text { focus on core business } \\
2-\text { reduce costs } \\
\text { 3- reduce investment in assets } \\
4-\text { increase levels of logistics service } \\
5-\text { increase control of logistics activities } \\
6-\text { acquire more flexibility in logistics } \\
\text { 7- } \text { operations } \\
\text { 8- bring more efficiency in the execution of } \\
\text { 9- improvement in used IT } \\
\text { 10- expand markets }\end{array}$ & $\begin{array}{l}1=\text { yes, } \\
\text { (agree) } \\
0=\text { no, } \\
\text { (disagree) }\end{array}$ & $\begin{array}{l}\text { Nominal } \\
\text { (dummy) }\end{array}$ \\
\hline
\end{tabular}

The second research question, the existence of a significant relationship between components of the dimensions of logistics sophistication and drivers of the outsourcing of logistics activities, was addressed by means of simple logistical regression analysis (Hair, Anderson, \& Tatham, 1998). This analysis has advantages over discriminant analysis in the separation of two groups of data (to present or not a certain driver) as a function of a certain criterion (dimension of sophistication of logistics organization), due to its superior flexibility. Its use and interpretation are analogous to simple linear regression analysis (Kleinbaum, Kupper, \& Muller, 1998), and there is no need to ensure the normality of data covariance matrices (Hair et al., 1998). A .10 percent level of significance was considered acceptable in this type of mainly exploratory logistics research (Mentzer \& Flint, 1997).

\section{RESULTS AND DISCUSSION}

Results leading to the identification of dimensions underlying the logistics sophistication constructs based on survey results with Brazilian shippers are shown in Table 5. They consist of those with load factors greater than .50 and eigenvalues greater than 1. According to Tabachnik and Fidell (2001), only load factors greater than .50 (25\% overlap in variance) should be interpreted and, in such cases, there are grounds to indicate a good measure of the factor. In the case of the present analysis, six factors represent different dimensions of sophistication of logistics organization. 
Table 5: Results of the Extraction of Factors of Logistics Sophistication

\begin{tabular}{|c|c|c|c|c|c|}
\hline $\begin{array}{l}\text { Factor } 1 \text { - } \\
\text { Sophistication } \\
\text { in Tracking } \\
\text { [STR] }\end{array}$ & $\begin{array}{l}\text { Factor } 2- \\
\text { Sophistication } \\
\text { in Supplier } \\
\text { Relationship } \\
\text { [SSR] }\end{array}$ & $\begin{array}{l}\text { Factor } 3- \\
\text { Sophistication } \\
\text { in Materials } \\
\text { Handling } \\
{[\mathrm{SMH}]}\end{array}$ & $\begin{array}{l}\text { Factor } 4- \\
\text { Sophistication } \\
\text { in Performance } \\
\text { Monitoring } \\
{[\mathrm{SPM}]}\end{array}$ & $\begin{array}{l}\text { Factor 5- } \\
\text { Sophistication } \\
\text { in Operations } \\
\text { Scheduling } \\
\text { [SOS] }\end{array}$ & $\begin{array}{l}\text { Factor } 5- \\
\text { Sophistication } \\
\text { in } \\
\text { Organizational } \\
\text { Formalization } \\
\text { [SOF] }\end{array}$ \\
\hline $\begin{array}{l}\text { Radio frequency } \\
(0.77 ; 0.46 ; \\
0.74) \\
\text { Bar coding } \\
(0.70 ; 0.19 ; \\
0.68) \\
\text { Loading status } \\
\text { monitoring } \\
(0.68 ; 0.26 ; \\
0.56)\end{array}$ & $\begin{array}{l}\text { Purchase } \\
\text { scheduling } \\
(0.66 ; 0.30 ; \\
0.69) \\
\text { Supplier } \\
\text { management } \\
(0.74 ; 0.53 ; \\
0.68) \\
\text { EDI }(0.52 ; 0.05 ; \\
0.32)\end{array}$ & $\begin{array}{l}\text { Separation } \\
(0.73 ; 0.38 ; \\
0.85) \\
\text { Address } \\
\text { systems }(0.85 ; \\
0.69 ; 0.83)\end{array}$ & $\begin{array}{l}\text { Performance in } \\
\text { cost }(0.67 ; 0.33 \text {; } \\
0.60) \\
\text { Performance in } \\
\text { service }(0.77 \text {; } \\
0.50 ; 0.66)\end{array}$ & $\begin{array}{l}\text { Routing }(0.51 ; \\
0.21 ; 0.50) \\
\text { ERP systems } \\
(0.59 ; 0.29 ; \\
0.69)\end{array}$ & $\begin{array}{l}\text { Hierarchical } \\
\text { level of chief } \\
\text { logistics } \\
\text { executive }(0.89 \text {; } \\
1.13 ; 0.94)\end{array}$ \\
\hline \multicolumn{6}{|c|}{ Percent of variance explained by factor } \\
\hline $13.8 \%$ & $12.0 \%$ & $9.7 \%$ & $8.5 \%$ & $6.8 \%$ & $6.6 \%$ \\
\hline
\end{tabular}

$\mathrm{KMO}=.626$; Chi-square $=305.409$ (sig. $=.000$ ); Letters in brackets are the coding of the dimensions for the purposes of further analyses in this paper. Figures in brackets indicate respectively the factor loading; the factor coefficient for the standardized variables; and variable commonalities.

It was therefore possible to identify the six dimensions indicated in Table 5, corresponding to each of the extracted factors. The dimensions of sophistication calculated on the basis of the standardized variables represent a tested and valid scale for measuring logistics sophistication, as indicated by the variates below:

. STR $=0.46$ [radio-frequency $]+0.19$ [bar coding $]+0.26$ [loading status monitoring $]$

. $\mathrm{SSR}=0.30$ [purchase scheduling $]+0.53$ [supplier management $]+0.05$ [EDI]

. $\mathrm{SMH}=0.33$ [separation] +0.50 [address systems]

. $\mathrm{SPM}=0.33$ [cost monitoring] +0.50 [service monitoring]

. $\mathrm{SOS}=0.21$ [routing $]+0.29[$ ERP systems $]$

. $\mathrm{SOF}=1.13$ [hierarchical level of top logistics executive]

Results in terms of frequency of 'yes' answers for the drivers of logistics outsourcing in the sample of shippers are shown in Table 6. 
Table 6: Frequency of Affirmative Answers for Drivers of Logistics Outsourcing

\begin{tabular}{|l|l|l|}
\hline Possible driver of logistics outsourcing & \% of affirmative answers & Rank \\
\hline $1-\quad$ focus on core business & 76.3 & 2 \\
\hline $2-\quad$ reduce costs & 84.9 & 1 \\
\hline $3-\quad$ reduce investment in assets & 66.7 & 4 \\
\hline $4-\quad$ increase levels of logistics service & 57.0 & 5 \\
\hline $5-\quad$ increase levels of control of logistics activities & 29.0 & 9 \\
\hline $6-\quad$ acquire more flexibility in logistics operations & 67.7 & 3 \\
\hline $7-\quad$ bring more efficiency to logistics operations & 44.1 & 6 \\
\hline $8-\quad$ bring more know-how for new logistics ideas & 35.5 & 7 \\
\hline 9- improve used ITs & 30.1 & 8 \\
\hline 10- expand markets & 21.5 & 10 \\
\hline
\end{tabular}

These results are consistent with previous studies (for instance, Boyson et al., 1999; Szymankiewicz, 1994), but tend to show that the important drivers for over 50 percent of the sample - cost reduction, focus on core business, flexibility, investment reduction, and improvement of service levels offered to customers - are linked to basic cost/service considerations. More sophisticated concerns, on the other hand, such as logistics control, innovation and improvement in IT technologies, as well as market expansion, are much less frequently mentioned.

Results for the logistical regression analysis of the relationship between the dimensions of sophistication of the logistics organization and drivers of the outsourcing of logistics activities are shown in Table 7 below.

Table 7: Relationships between Sophistication Dimensions (Factors) and Drivers of Logistics Outsourcing

\begin{tabular}{|c|c|c|c|c|c|c|c|c|c|c|c|c|c|c|}
\hline \multirow{2}{*}{$\begin{array}{l}\text { Drivers of } \\
\text { logistics } \\
\text { outsourcing }\end{array}$} & \multicolumn{2}{|c|}{ Model } & \multicolumn{2}{|c|}{ SSR } & \multicolumn{2}{|c|}{ SMH } & \multicolumn{2}{|c|}{ SPM } & \multicolumn{2}{|c|}{ SOS } & \multicolumn{2}{|c|}{ SOF } & \multicolumn{2}{|c|}{ STR } \\
\hline & $\begin{array}{l}\text { Chi } \\
\text { square }\end{array}$ & Sig. & B & Sig. & B & Sig. & B & Sig. & B & Sig. & B & Sig. & B & Sig. \\
\hline $1(8 \%)$ & 5.33 & .50 & .39 & .15 & $(.43)$ & .19 & .44 & .11 & .16 & .54 & $(.04)$ & .89 & $(.02)$ & .93 \\
\hline $2(18 \%)$ & $\begin{array}{l}10.37 \\
\end{array}$ & .11 & .34 & .27 & .18 & .61 & $(.56)$ & .08 & .08 & .80 & $(.82)$ & .04 & $(.12)$ & .73 \\
\hline $3(8 \%)$ & 5.37 & .50 & $(.00)$ & 1.00 & $(.12)$ & .65 & $(.08)$ & .75 & .45 & .06 & .18 & .44 & $(.12)$ & .64 \\
\hline $4(6 \%)$ & 62 & .59 & $(.23)$ & .35 & .31 & .22 & .29 & .21 & $(.15)$ & .52 & .03 & .88 & .03 & .90 \\
\hline $5(3 \%)$ & 2.28 & .89 & .14 & .59 & .27 & .33 & .16 & .58 & $\begin{array}{l}.09) \\
\end{array}$ & .71 & $(.00)$ & .99 & $\begin{array}{l}(.27) \\
\end{array}$ & .32 \\
\hline $6(18 \%)$ & 12.50 & .05 & $(.51)$ & .08 & .55 & .05 & .15 & .54 & $(.30)$ & .27 & .66 & .02 & .28 & .32 \\
\hline $7(7 \%)$ & 4.70 & .58 & .06 & .80 & .21 & .42 & .09 & .69 & $(.41)$ & $\begin{array}{l}.07 \\
\end{array}$ & .14 & .55 & .19 & .44 \\
\hline $8(17 \%)$ & 12.65 & .05 & $(.06)$ & .81 & .78 & .01 & $\begin{array}{l}(.48) \\
\end{array}$ & .07 & $\begin{array}{l}(.16) \\
\text { (1) }\end{array}$ & .52 & .38 & .12 & $(.42)$ & .15 \\
\hline $9(14 \%)$ & 10.00 & .12 & $(.33)$ & .23 & .85 & .01 & .16 & .52 & $(.04)$ & .87 & .17 & .47 & $(.02)$ & .95 \\
\hline $10(30 \%)$ & 19.83 & .00 & $(.15)$ & .62 & .23 & .48 & .13 & .67 & .42 & .19 & 1.37 & .00 & .06 & .85 \\
\hline
\end{tabular}

Numbers in the first column relate to drivers in Table 4 and percentages in brackets correspond to Nagelkerke's $R^{2}$; the figures in bold represent significant relationship results. 
The driver expand markets is explained by organizational formalization, and higher levels of organizational formalization are significantly related to a higher proportion of affirmative answers to this driver. Complex supply chains have enhanced the role of logistics managers, who seem to recognize the need to outsource logistics activities so as to tap into the knowledge on customs and infrastructure in target markets (Razzaque \& Sheng, 1998).

The driver acquire more flexibility in logistics operations is explained by supplier relationships, materials handling and organizational formalization. Coefficient signs indicate that shippers with higher levels of organizational formalization in logistics, intensive use of IT in materials handling and less sophistication in their relationship with suppliers are significantly related to a higher proportion of affirmative answers to this driver. As pointed out by Sink and Langley (1997), purchasing services is more complex and uncertain than the acquisition of products. The sophistication in the logistics organizational formalization seems to indicate that shippers are aware of the flexibility benefits that may be acquired through logistics outsourcing, while at the same time they are still learning to establish the necessary supplier relationships with 3PL providers.

The driver bring more know-how for the generation of new logistics solutions is simultaneously explained by materials handling and performance monitoring, with coefficient signs indicating that shippers with intensive use of IT in materials handling and low levels of performance monitoring are significantly related to a higher proportion of affirmative answers to this driver. The first relationship seems to be quite straightforward, indicating that shippers turn to logistics service providers that can complement their own expertise in significant areas, in particular the increasingly important use of IT solutions.

The driver reduce costs is explained by organizational formalization and performance monitoring, with coefficient signs indicating that shippers with low levels of organizational formalization and performance monitoring are significantly related to a higher proportion of affirmative answers to this very basic driver of the outsourcing of logistics activities. Previous literature indicates that cost reduction is the most prevalent reason for shippers in different industries to engage in the outsourcing of logistics activities (Sahay \& Mohan, 2006; Wilding \& Juriado, 2004). Therefore, the association of this driver with low levels of sophistication, especially in terms of the importance of logistics in the organization and of the degree of performance monitoring, as uncovered here, appears to be justified.

The driver improvement in used IT is explained only by sophistication in materials handling, and the coefficient sign indicates that shippers with intensive use of IT to handle materials are significantly related to a higher proportion of affirmative answers to this driver. Again, this result is not surprising, as both variables in the materials handling sophistication factor are related to the use of software and decision support systems in logistics activities.

The driver reduce investment in assets is explained only by sophistication in scheduling of operations, with a coefficient sign that indicates that shippers with low levels of adoption of IT for scheduling their operations are significantly related to a higher proportion of affirmative answers to this driver. Even though no readily apparent rationale for this finding can be found in previous literature, it may be an indication that shippers who are not using ERP or routing systems outsource most of their logistics operations and, therefore, are driven by the perspective of reducing investment in assets.

These results do not seem to conflict with existing logistics outsourcing literature. They tend to show that shippers with higher levels of logistics organizational formalization, i.e., more sophisticated in terms of logistics organization, are motivated to outsource in order to acquire more operational flexibility, compensating for weaker supplier relations. This, in turn, may allow them to expand their markets. On the other hand, as expected, shippers with lower levels of logistics organizational formalization tend to be driven by more basic and frequent logistics concerns, such as cost and asset investment reduction. 
It is also interesting to observe that sophistication in the use of materials handling information technology seems to lead shippers to outsource logistics activities both to improve the technologies they use and to bring in technology that may represent innovative solutions to their logistics operations in a rapidly expanding market. Even though both these drivers were not strongly chosen by surveyed shippers, it points to an apparent technology focus in a subset of Brazilian shippers.

There is less a clear picture in terms of the relationships of drivers of logistics outsourcing and other components of logistics sophistication. Outsourcing in order to focus on core business, the second most frequently mentioned driver, does not appear to be influenced by any component of logistics sophistication, as well as improvement in logistics service, the fifth most frequently mentioned driver of outsourcing. One would, in fact, assume that shippers with more sophisticated logistics organizations would be induced to outsource by concerns with the need to provide better service to customers.

\section{CONCLUSIONS}

The contribution of this paper is two-fold. On the theoretical side, a valuable scale for the measurement of the logistics sophistication construct was built and validated, representing an index of logistics sophistication of shippers based on use of IT, performance measurement and formalization of the logistics organization. On the other hand, the managerial implication of this possibility of measuring the degree of sophistication of the logistics organization of shippers is that it may be used as a basis for segmenting the market met by logistics service providers. For instance, do shippers in a certain industry show a higher sophistication in their logistics organization than those of other industries? This may imply different concerns in terms of service offer, negotiation conditions, etc. Future studies, in fact, may investigate this issue, seeking to discriminate several aspects of logistics outsourcing based on this composite characteristic of shippers. A clustering approach might be used to identify segments of shippers according to characteristics in terms of sophistication elements, which could, in turn, be investigated for differences in approaches to outsourcing, not only in terms of drivers but also of types of activities outsourced and selection criteria for third party providers, among others.

The second question in this paper dealt with the possibility of finding relationships between drivers of the outsourcing of logistics activities and identified dimensions of logistics sophistication in order to gain a deeper understanding of particular elements that drive the outsourcing of logistics activities. In general, a relationship could be established, as expected, between the degree of formalization of the logistics organization and certain possible drivers of logistics outsourcing, such as the search for greater flexibility and cost reduction. A link was also uncovered between the use of IT and outsourcing in order to enable the shipper to take advantage of innovation in logistics software and solutions. However, several important drivers, such as the wish to improve service levels and focus on core business could not be significantly related to any of the components of sophistication in logistics activities. Future studies, with alternative approaches, such as the clustering of shippers according to their logistics sophistication characteristics, may help to further develop knowledge in this very important field of research.

\section{REFERENCES}

Amstel, W. P. van, \& Starreveld, D. W. (1993). Does your company need a logistical executive?. The International Journal of Logistics Management, 4(1), 48-58.

Bardi, E. J., \& Tracey, R. (1991). Transportation outsourcing: a survey of US practices. International Journal of Physical Distribution and Logistics Management, 21(3), 15-21. 
Bhatnagar, R., Sohal, A. S., \& Millen, R. (1999). Third party logistics services: a Singapore perspective. International Journal of Physical Distribution and Logistics Management, 29(9), 569-587.

Bowersox, D. J., \& Closs, D. J. (1996). Logistical management: the integrated supply chain process. New York, NY: McGraw-Hill.

Bowersox, D. J., Closs, D. J., \& Stank, T. P. (1999). $21^{\text {st }}$ century logistics: making supply chain integration a reality. Oak Brooks, Ill.: Council of Logistics Management.

Bowersox, D. J., \& Daugherty, P. J. (1995). Logistics paradigms: the impact of information technology. Journal of Business Logistics, 16(1), 65-80.

Bowersox, D. J., Daugherty, P. J., Dröge, C. L., Germain, R. N., \& Rogers, D. S. (1992). Logistical excellence: it's not business as usual. Burlington, VT: Digital Press.

Boyson, S., Corsi, T., Dresner, M., \& Rabinovich, E. (1999). Managing effective third party logistics relationships: what does it take?. Journal of Business Logistics, 20(1), 73-100.

Buck, D. (1988). Changing to contract distribution. Management Decision, 26(5), 42-47.

Capgemini (2006). 2006 Third party logistics: results and findings of the $11^{\text {th }}$ Annual Study. Retrieved October 6, 2007, from http//www.at.capgemini.com/m/at/tl/Third-Party_Logistics_2006.pdf

Cavinato, J. L. (1989). The logistics of contract manufacturing. International Journal of Physical Distribution and Logistics Management, 19(1), 13-20.

Chee-Chuong, S., \& Chew-Been, T. (1999). Strategic posture of logistics service providers in Singapore. International Journal of Physical Distribution \& Logistics Managemen, 29(9), 588605.

Closs, D. J., Goldsby, T. J., \& Clinton, S. R. (1997). Information technology influences on world class logistics capability. International Journal of Physical Distribution \& Logistics Management, 27(1), 4-17.

Daugherty, P. J., \& Droge, C. (1997). Organizational structure in divisionalized manufacturers: the potential for outsourcing logistical services. International Journal of Physical Distribution and Logistics Management, 27(5/6), 337-349.

Daugherty, P. J., Stank, T. P., \& Rogers, D. S. (1992). The impact of formalization of warehousing firms. The International Journal of Logistics Management, 3(2), 1-15.

Fernie, J. (1989). Contract distribution in multiple retailing. International Journal of Physical Distribution and Logistics Management, 19(7), 2-35.

Figueiredo, K. F., Fleury, P. F., \& Wanke, P. (2003). Logística e gerenciamento da cadeia de suprimentos: planejamento do fluxo de produtos e de recursos. São Paulo, SP: Atlas.

Hair, J. F., Anderson, R. E., \& Tatham, R. L. (1998). Multivariate data analysis. New York, NY: Prentice-Hall.

Kleinbaum, D., Kupper, L., \& Muller, K. (1998). Applied regression analysis and other multivariate methods. New York, NY: Duxbury Press.

Knemeyer A. M., \& Murphy, P. R. (2004). Evaluating the performance of third-party logistics arrangements: a relationship marketing perspective. Journal of Supply Chain Management, $40(1), 35-51$. 
Laarhoven, P. van, Berglund, M., \& Peters, M. (2000). Third-party logistics in Europe - five years later. International Journal of Physical Distribution and Logistics Management, 30(5), 425-442.

Lambert, D. M., \& Stock, J. R. (1998). Fundamentals of logistics management. New York, NY: IrwinMcGraw Hill.

Lavalle, C., \& Fleury, P. F. (2000). Avaliação da organização logística em empresas da cadeia de suprimentos de alimentos. Revista de Administração Contemporânea, 4(1), 47-67.

Lieb, R. C., \& Randall, H. L. (1996). A comparison of the user of third-party logistics services by large american manufacturers, 1991, 1994 and 1995. Journal of Business Logistics, 17(1), 5562.

Londe, B. J. la, \& Maltz, A. B. (1992). Some propositions about outsourcing the logistics functions. The International Journal of Logistics Management, 3(1), 1-11.

Mentzer, J., \& Flint, D. J. (1997). Validity in logistics research, Journal of Business Logistics, 18(1), 199-216.

Morris, J. (2004, December 1). 3PLs Gain nearly half of logistics budgets, foresee continued growth. Multichannel Merchant. Retrieved January 03, 2005, from http://multichannelmerchant.com/opsandfulfillment.com/ advisor/3PLs-growth/index.html.

Rabinovich, E., Windle, R., Dresner, M., \& Corsi, T. (1999). Outsourcing of Integrated Logistics Functions: an examination of industry practices. International Journal of Physical Distribution and Logistics Management, 29(6), 353-373.

Rao, K., \& Young, R. R. (1994). Global supply chains: factors influencing outsourcing of logistics functions. International Journal of Physical Distribution and Logistics Management, 24(6), 1119.

Razzaque, A. M., \& Sheng, C. C. (1998). Outsourcing of logistics functions: a literature survey. International Journal of Physical Distribution and Logistics Management, 28(2), 89-107.

Rogers, D. S., Daugherty, P. J., \& Stank, T. P. (1992). Enhancing service responsiveness: the strategic potential of EDI. International Journal of Physical Distribution and Logistics Management, 22(8), 15-20.

Sahay, B. S., \& Mohan, R. (2006). 3PL practices: an Indian perspective. International Journal of Physical Distribution and Logistics Management, 36(9), 666-689.

Sheffi, Y. (1990). Third party logistics: present and future prospects. Journal of Business Logistics, 11(2), 27-39.

Selviaridis, K, \& Spring, M. (2007). Third party logistics: a literature review and research agenda. The International Journal of Logistics Management, 18(1), 125-150.

Sink, H. L., Langley, C. J., Jr., \& Gibson, B. J. (1996). Buyer observations of US third party logistics market. International Journal of Physical Distribution and Logistics Management, 26(3), 38-46.

Sink, H. L., \& Langley, C. J., Jr. (1997). A managerial framework for the acquisition of third-party logistics services. Journal of Business Logistics, 18(2), 163-189.

Sohail, M. S., Bhatnagar, R., \& Sohal, A. S. (2006). A comparative study on the use of third party logistics services by singaporean and malaysian firms. International Journal of Physical Distribution and Logistics Management, 36 (9), 690-701. 
Stank, T. P., Rogers, D. S., \& Daugherty, P. J. (1994). Benchmarking: applications by third party warehousing firms. Logistics and Transportation Review, 30(1), pp. 55-72.

Szymankiewicz, J. (1994). Contracting out or selling out? Survey into the current issues concerning the outsourcing of distribution. Logistics Management, 7(1), 28-35.

Tabachnik, B. G., \& Fidell, L. S. (2001). Using multivariate statistics. Boston, MA: Allyn and Bacon.

Tecnologística online. (2006). Prêmio Volvo. Retrieved June 06, 2007, from http://www.tecnologistica.com.br/site/volvo2006_01.asp

Wilding, R., \& Juriado, R. (2004). Customer perceptions on logistics outsourcing in the european consumer goods industry. International Journal of Physical Distribution and Logistics Management, 34(8), 628-644. 